\title{
TWO NEW SPECIES OF ORIBATID MITES (ACARI: ORIBATIDA) FROM VIETNAM
}

\author{
QUANG MANH VU \\ Hanoi National University of Education, Vietnam \\ SERGEY G. ERMILOV \\ Center of Independent Examinations-NN, Russia \\ DUY TRINH DAO \\ Hanoi University of Education No2, Vietnam
}

\begin{abstract}
Two new species of oribatid mites (Acari: Oribatida) Aokiella xuansoni sp. nov. Vu, Ermilov et Dao (Carabodidae) and Papillacarus benenensis sp. nov. Vu, Ermilov et Dao (Lohmanniidae Berlese, 1916), are described. Both are based on adult specimens and collected in the soil ecosystem, from the Xuan Son National park, province of Phu Tho and from the Ben En national park, Thanh Hoa province, Vietnam.

Aokiella xuansoni sp. nov. is recognized by the small size of body, the surface of body with large and small foveolae; the straight, thickish, interiorly directed two pairs of setae ( $c 1$ longer than $c 2)$; the rather short setae $d a$ and $l a$, which obviously not reaching bases of setae $d m$ and $l m$, respectively.

Papillacarus benenensis sp. nov. is recognized by the large size of body; the surface of body with reticulate sculpturing; rostrum undulate; prodorsal setae long, slightly thickened proximally, conspicuously ciliate on both sides; sensilli with 15 long, pectinate branches; one pair of medially incomplete transversal bands; notogaster with 18 pairs of long, conspicuously ciliate setae; posterior half of notogaster strongly neotrichous (more than 50 pairs of small, branched setae); genital setae heterogeneous; epimeres neotrichous (setal formula: 10-9-5-4).
\end{abstract}

Keywords: Acari, Oribatida, Aokiella, Papillacarus, new species, soil ecosystem, Xuan Son, Ben En, national park, Vietnam.

Vietnam is a highly interesting region in zoogeographical aspect. Principally the whole country is in the Oriental region. However there is a differentiation between the northern and southern parts of the country and even between different sub-regions of the northern and the southern parts $[16,17]$. Oribatid mites are one of the richest acarine groups in the soil ecosystem. The oribatid fauna of Vietnam was first studied by Balogh and Mahunka (1967). In the 1970-1980's investigation on oribatid fauna of Vietnam had been studied more actively, with the works of Rajski and Szudrowicz (1974), Vu and Nguyen (1982), Golosova (1984), Vu (1984), Vu et al. (1985, 1987), Jeleva and Vu (1987), Tsonev and $\mathrm{Vu}$ (1987), $\mathrm{Vu}$ and Jeleva (1987), Nguyen and $\mathrm{Vu}$ (1988), Mahunka (1987, 1988, 1989).
In the last years, studied have been done onthe faunal composition, population density, spatial and vertical distribution of soil oribatids in Vietnam. However these studies are still not enough for such very rich group of soil microarthropods, especially in the aspect of their species biodiversity. $\mathrm{Vu}$ in his recent general work (2007) introduced an oribatid fauna of Vietnam with 150 known species. It is a very few number in comparison with the real one of oribatid species that may exist in a diversitified nature of the country.

Aokiella is a very small genus of the oribatid mite family Carabodidae that was proposed by Balogh and Mahunka (1967) with Aokiella florens Balogh et Mahunka as type species. Currently, the genus comprises 2 named species. Both species are restricted to geographical 
distribution: Aokiella florens has been found only in Vietnam [3, 17] and Aokiella rotunda Hammer, 1979 is known only from the very distant islands of Java and Sri Lanka. Subias (2009) considered Aokiella as a subgenus of Odontocepheus Berlese, 1913, but since he presented no supporting information for this change we recognize the original generic rank.

Papillacarus (=Vepracarus) is a genus of the family Lohmanniidae (Balogh 1961, Balogh \& Balogh, 1987) that was proposed by Kunst (1959) with Lohmannia murcioides aciculata Berlese, 1913 as type species. Currently, it genus comprises about 25 named species [11], the majority of which (17 species) have restricted geographical distribution. For the Vietnamese fauna this genus has been recorded with 3 species namely $P$. aciculatus (Berlese, 1905), $P$. arboriseta Vu et Jeleva, 1987 and $P$. undirostratus Aoki, 1964 [15, 17].

In the present work, we propose and describe a new species of each mentioned genus collected from Vietnam, based on adult specimens. This is the first paper of our works in which we will describe a new oribatid species among the rich materials obtained from Vietnam.

\section{MATERIALS AND METHODS}

\section{Study Area}

Ben En National Park was established in 1992, by the Decision No. 33/CT of the Vietnamese Prime Minister. Its ttotal area is 16,634 ha including 8,544 ha of natural forest. This national park is moderately important for the conservation of biodiversity. It protects one of the few surviving areas of lowland evergreen forest in north-central Vietnam. Much of the wildlife found here has been categorized as endangered or rare. It spans across Nhu Xuan and Nhu Thanh districts, $36 \mathrm{~km}$ South-West of Thanh Hoa city, Thanh Hoa province. The coordinates are $19^{\circ} 31^{\prime}-19^{\circ} 40^{\prime} \mathrm{N}$ and $105^{\circ} 23^{\prime}$ $105^{\circ} 35^{\prime} \mathrm{E}$. The park is surrounded by hills and mountains, ranging from 20 to $500 \mathrm{~m}$ above see level, with most area being below $200 \mathrm{~m}$. The annual average temperature is $23.1^{\circ} \mathrm{C}$ and the average humidity is $85 \%$.

The forested area of Xuan Son was included in Decision Number 194/CT by the Vietnamese Chairman of the Council of Ministers, in 1986. Its status was revised from nature reserve to national park in April of 2002. At present the Xuan Son national park occupies an area 15,048 ha including a strict protection area of 11,148 ha. Xuan Son national park is located in Thanh Son district, Phu Tho province, northern Vietnam. It is located on $21^{\circ} 03^{\prime}-21^{\circ} 12^{\prime} \mathrm{N}$. latitude and $104^{\circ} 51^{\prime}-105^{\circ} 01^{\prime}$ E. longitude. The park borders Hoa Binh and Son La provinces. About $40 \%$ of the total land area is over $700 \mathrm{~m}$ in elevation. A soil mountain, i.e. the low one without rocky outcroppings, runs along the northeast at an elevation of from 600-700 m. The native vegetation types at Xuan Son are lowland and lower montane evergreen forest, and lowland and lower montane limestone forest. The predominant soil type in the study region is feralite (acrisols), developed from sediments and limestone. The study area is covered with trees, shrubs and herbs mainly of families Fagaceae, Sapotaceae, Magnoliaceae, Aceraceae, Ericaceae, Theaceae, Lauraceae. The studied habitats are slightly disturbed, exhibit high plant biodiversity, and contain a litter layer of about $5 \mathrm{~cm}$ deep. These habitats are actually natural and human-impacted forests. Average annual temperature in this region is ca. $22.5^{\circ} \mathrm{C}$, average annual rainfall is ca. $1,826 \mathrm{~mm}$ and the average humidity is ca. $86 \%[16]$.

\section{Study technics}

The locality and habitat characterization of the Aokiella xuansoni sp. nov. Vu, Ermilov et Dao and Papillacarus benenensis sp. nov. Vu, Ermilov et Dao are given in the "material examined" section.

Specimens were studied in lactic acid, mounted on temporary cavity slides for the duration of the study. Body length was measured in lateral view, from the tip of the rostrum to the posterior edge of the ventral plate, to avoid discrepancies caused by different degrees of notogastral distension. Notogastral length was also measured in lateral view, from anterior to posterior edge; notogastral width refers to the maximum width in dorsal aspect. Length of body setae was measured in lateral aspect. For Papillacarus terminology used in 
this paper follows Grandjean (1950).

\section{RESULTS}

\section{Aokiella xuansoni sp. nov. Vu, Ermilov et} Dao (Fig. 1)

Holotype: Holotype (female) is deposited in the collection of the Zoological Institute of Russian Academy of Sciences, St. Peterburg, Russia.

Paratype: Paratypes (4 specimens), two are deposited in the collection of the Center for Biodiversity Resources Education \& Development (CEBRED), Hanoi national University of Education, Vietnam; and two - in the collection of the Zoological Institute of Russian Academy of Sciences, St. Peterburg, Russia.

Type locality: Ben En national park, Thanh Hoa province, central Vietnam and Xuan Son national park, Phu Tho province, northern

\section{Vietnam.}

Diagnosis: With characters of Aokiella that was proposed by Balogh and Mahunka (1967), and summarized by Balogh and Balogh (1992). The new species is recognized by the small sizes of body, the surface of body with large and small foveolae; the straight, thickish, interiorly directed two pairs of setae $\left(c_{1}\right.$ longer than $\left.c_{2}\right)$; the rather short setae $d a$ and $l a$, of with obviously do not reach bases of setae $d m$ and lm, respectively.

Description: Measurements and form of body. Holotype: body length 291, length of notogaster 180, width of notogaster 123; paratype: body length 287; length of notogaster 176; width of notogaster 123. This species is smallest in genus (body length 373 - for Aokiella florens, body length 310 - for Aokiella rotunda). Body elongate, more than twice as long as wide; typical form for carabodoid mites.

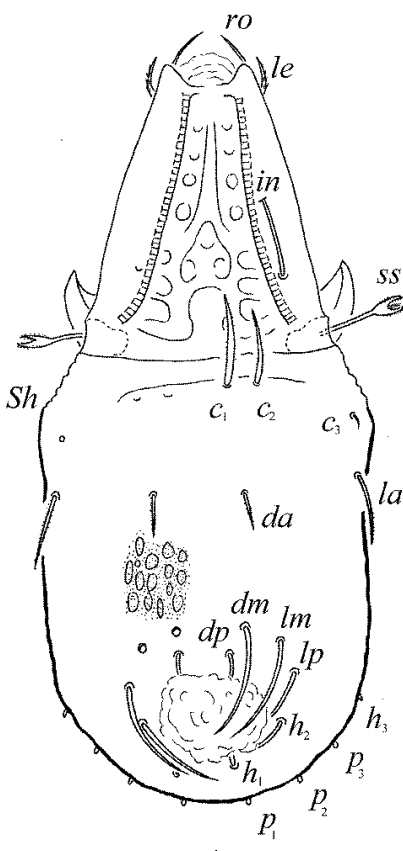

A

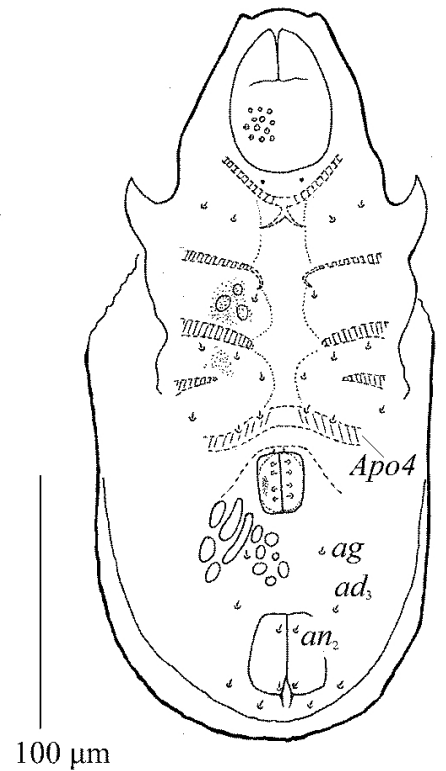

B

Fig. 1. Aokiella xuansoni sp. nov. Vu, Ermilov et Dao (leg removed)

A. dorsal view; B. ventral view.

Integument. Body color brown. Surface of body with thick cerotegument, roughened by minute granules. Surface of prodorsum with several large (maximum diameter 12) and smaller foveolae. Surface of notogaster with dense foveolae (maximum diameter 4).
Prodorsum. Roughly triangular in outline, occupying about $2 / 5$ of total body length. Rostrum weakly rounded in dorsal view. Lamellae long, wide, slightly converging. Rostral setae (ro) 20 in length, smooth, directed anteromediad. Lamellar setae (le) hardly longer 
(24 in length), thicker, barbed. Interlamellar setae (in) broken or absent in both specimens (only alveoli are present), originating in basal half of lamellae. Sensilli (ss) 41 in length, apically incrassate, resembling a flower-bud. Bothridia funnel-shaped, with large opening directed posterolaterally.

Notogaster. About 1.3 times as long as wide. Anterior margin truncate, posterior margin rounded. With anterolateral hardly visible shoulder (Sh). Fifteen pairs of notogastral setae, all visible in dorsal view. Anterior part with two pairs $\left(c_{1}, c_{2}\right)$ straight, thickish, anteriorly directed; $c_{1}$ longer than $c_{2}$. Six pairs of notogastral setae $\left(d m, l m, d p, l p, h_{1}\right.$, $h_{2}$ ) longest, setiform, curved, located in group on posterior half of notogaster. Setae $d a$ and $l a$ shorter than those in group, straight, sometimes weakly curved; la little longer than $d a$; their ends obviously do not reach bases of setae $d m$ and $l m$. respectively. Setae $l a$ and small setae $c_{3}$ located on humeral corner of notogaster. Four pairs posteromarginal setae $\left(h_{1}, p_{1}-p_{3}\right)$ very short, thickish, spiniform. Lyrifissure and opisthosomal gland opening not found.

Gnathosoma. Subcapitulum diarthric. Details were not studied.

Epimeral region. Epimeral setal formula: 21-3-3; setae minute. Apodemes 4 (Apo 4) complete. Pedotectum I well developed, large.

Anogenital region. With irregularly polygonal sculpturing. Genital and anal plates with reticulate pattern (cells very small, oblong). Posterior median margin of anal plates with acute, spiniform, chitinous processes. Two pairs of anal setae, three pairs of adanal setae, one pair of aggenital setae, five pairs of genital setae. All setae minute, located as in other species of genus.

Legs. Tarsi with one claw. Details were not studied.

Table 1

Morphological differences of described species of genus Aokiella*

\begin{tabular}{|c|c|c|c|}
\hline Character & $\begin{array}{c}\text { Aokiella xuansoni sp. } \\
\text { nov. }\end{array}$ & Aokiella florens & Aokiella rotunda \\
\hline & $\begin{array}{l}\text { With several large and } \\
\text { smaller foveolae }\end{array}$ & Punctuate & $\begin{array}{l}\text { With numerous small } \\
\text { foveolae }\end{array}$ \\
\hline & With dense foveolae & With dense foveolae & $\begin{array}{l}\text { With circularly arranged } \\
\text { structures }\end{array}$ \\
\hline $\begin{array}{l}\text { Form and } \\
\text { length of setae } \\
c_{1} \text { and } c_{2}\end{array}$ & $\begin{array}{l}\text { Thickish; shorter than } \\
\text { setae in centrodorsal } \\
\text { posterior part of } \\
\text { notogaster; } c_{1} \text { longer } \\
\text { than } c_{2}\end{array}$ & $\begin{array}{l}\text { No thickish; length as in } \\
\text { setae in centrodorsal } \\
\text { posterior part of } \\
\text { notogaster; } c_{1} \text { and } c_{2} \text { of } \\
\text { identical length } \\
\text { approximately }\end{array}$ & $\begin{array}{l}\text { No thickish; length as in } \\
\text { setae in centrodorsal } \\
\text { posterior part of } \\
\text { notogaster; } c_{1} \text { and } c_{2} \text { of } \\
\text { identical length } \\
\text { approximately }\end{array}$ \\
\hline $\begin{array}{l}\text { Length of } d a \\
\text { and } l a\end{array}$ & $\begin{array}{l}\text { Rather short; shorter } \\
\text { than setae in } \\
\text { centrodorsal posterior } \\
\text { part of notogaster; their } \\
\text { ends obviously do not } \\
\text { reach the bases of setae } \\
d m \text { and } l m\end{array}$ & $\begin{array}{l}\text { Rather long; length as in } \\
\text { setae in centrodorsal } \\
\text { posterior part of } \\
\text { notogaster; their ends } \\
\text { reach the bases of setae } \\
d m \text { and } l m\end{array}$ & $\begin{array}{l}\text { Rather long; length as in } \\
\text { setae in centrodorsal } \\
\text { posterior part of } \\
\text { notogaster; their ends } \\
\text { reach the bases of setae } \\
d m \text { and } l m\end{array}$ \\
\hline
\end{tabular}

Notes: *. Data for Aokiella florens from Balogh et Mahunka (1967); data for Aokiella rotunda from Hammer (1979).

Etymology: This species is named following the name of one of a very beautiful national parks distributed in northern Vietnam where the species was obtained.
Habitat: Ben En national park, Thanh Hoa province, central Vietnam: altitude of about 200 $\mathrm{m}$ above see level; from natural forest, in forest litter covering the soil surface ( 1 specimen) and 
in the soil surface layer of $0-10 \mathrm{~cm}$ (1) and from Human-impacted forest, in the soil layer of 11$20 \mathrm{~cm}$ (1), on July 15, 2008; and from Humanimpacted forest, in the soil layer of 11-20 cm (1), January 10, 2009; Xuan Son national park, Phu Tho province, northern Vietnam: altitude of about 300-400 m above sea level, Humanimpacted forest, in the soil layer of $11-20 \mathrm{~cm}$ (1), April 22, 2005.

Distribution: Until this moment it is recorded only in Vietnam; probably endemic.

Remarks: Aokiella xuansoni sp. nov. Vu, Ermilov et Dao is easily distinguishable from other species of Aokiella by the surface pattern of the prodorsum and notogaster, the form and length of setae $c_{1}$ and $c_{2}$, and the length of setae $d a$ and $l a$ (see table 1$)$.
2. Papillacarus benenensis sp. nov. Vu, Ermilov et Dao (fig. 2)

Holotype: Holotype is deposited in the collection of the Zoological Institute of Russian Academy of Sciences, St. Peterburg, Russia.

Paratype: Paratype (2 specimens) are deposited in the collection of the Center for Biodiversity Resources Education \& Development (CEBRED), Hanoi National University of Education, Vietnam, 136 Xuan Thuy Rd., Cau Giay, Vietnam; and in the collection of the Zoological Institute of Russian Academy of Sciences, St. Peterburg, Russia.

Type locality: Ben En national park, province of Thanh Hoa, central Vietnam; and Xuan Son national park, Phu Tho province, northern Vietnam.

Fig. 2. Papillacarus benenensis sp. nov. Vu, Ermilov et Dao (leg removed)

A. dorsal view; B. epimeral region; C. anogenital region.

Diagnosis: With characters of Papillacarus that was summarized by Balogh and Balogh (1992). The new species is recognized by the large sizes of body; surface of body with reticulate sculpturing; rostrum undulate; prodorsal setae long, slightly thickened proximally, conspicuously ciliate on both sides; sensilli with 15 long, pectinate branches; one pair of medially incomplete transversal bands; notogaster with 18 pairs of long, conspicuously 
ciliate setae; posterior half of notogaster strongly neotrichous (more than 50 pairs of small, branched setae); genital setae heterogeneous; epimeres neotrichous (setal formula: 10-9-5-4).

Description: Measurements. Holotype: body length 664, length of notogaster 415, width of notogaster 332 . This species is longest in genus With characteristic body shape for lohmannioid mites; twice as long as wide.

Integument: Body color yellow. Surface of all body with reticulate sculpturing, though only weakly visible on prodorsum.

Prodorsum: Roughly triangular form, occupying about $1 / 3$ of total body length. Anterior margin of rostrum undulate. Length of rostral setae 82, lamellar setae 94, interlamellar setae 86; exobothridial setae exa 94 in length, $\exp 118$. All setae weakly thickened proximally, conspicuously ciliate on both sides. Sensilli (ss) 82 in length, with 15 long, pectinate branches. Bothridia funnel-shaped.

Notogaster: 1.25 times as long as wide. One pair of incomplete transversal bands $\left(S_{3}\right)$ observable between rows of setae $c$ and $d$. Light elliptical cuticular area present near seta $d_{1}$. Posterior margin rounded. Setation both heteromorphic and strong neotrichous. With 18 pairs of long setae, weakly thickened proximally and conspicuously ciliate; length of centrodorsal setae: $f_{1}>d_{1}>e_{1} \approx c_{1}$. Posterior half of notogaster (posterior to setal row $f$ ) with more than 50 pairs small, branched neotrichous setae on each side (some broken, only alveoli present).

Gnathosoma. Details were not studied.

Epimeral region: Similar to that in other species of genus. Epimeres neotrichous, especially I and II; setal formula: 10-9-5-4. Most setae thin, with long, thin ciliate. Six pairs of setae longer, thicker. Median setae $3 a, 4 a$ thin, smooth.

Anogenital region: Similar to that of other species of genus, but length of setae differs. Anal (two pairs) and adanal (four pairs) setae long, weakly thickened proximally, conspicuously ciliate. Ends of anal and adanal setae well overreach insertion of next proximal seta, respectively. Genital setae heterogeneous: four lateral pairs long, six medial pairs shorter; divided among two pairs of plates as typical for genus.

Table 2

Morphological traits distinguishing Papillacarus benenensis from three similar species*

\begin{tabular}{|l|c|c|c|c|}
\hline \multicolumn{1}{|c|}{ Character } & $\begin{array}{c}\text { Papillacarus } \\
\text { benenensis sp. nov. }\end{array}$ & $\begin{array}{c}\text { Papillacarus } \\
\text { ogawai }\end{array}$ & $\begin{array}{c}\text { Papillacarus } \\
\text { cruzae }\end{array}$ & $\begin{array}{c}\text { Papillacarus } \\
\text { ramirezae }\end{array}$ \\
\hline $\begin{array}{l}\text { Length of body } \\
\text { (in } \mu \mathrm{m} \text { ) }\end{array}$ & 664 & 245 & $488-560$ & $469-545$ \\
\hline $\begin{array}{l}\text { Epimeral setal } \\
\text { formula (I-IV) }\end{array}$ & $10-9-5-4$ & $8-5-5-3$ & $8-5-3-4$ & $9-5-5-3$ \\
\hline $\begin{array}{l}\text { Transversal } \\
\text { bands on } \\
\text { notogaster }\end{array}$ & 1 pair & absent & absent & absent \\
\hline $\begin{array}{l}\text { Anal and } \\
\text { adanal setae }\end{array}$ & long & long & short & short \\
\hline Genital setae & long and short & long and short & short & short \\
\hline Rostral tooth & not present & not present & not present & present \\
\hline
\end{tabular}

Notes: *. Data for Papillacarus ogawai from Aoki (1965); data for Papillacarus cruzae and Papillacarus ramirezae from Corpuz-Raros (1979).

Legs. Tarsi with 1 claw. Details were not studied.
Etymology: This species is named following the name of one of a very beautiful 
national parks distributed in northern-central Vietnam where the species was obtained.

Habitat: Ben En national Park, province of Thanh Hoa, central Vietnam: altitude of about $200 \mathrm{~m}$ above see level, from Natural forest, in the soil surface layer of $0-10 \mathrm{~cm}$, July 15,2008 \& January 10, 2009.

Xuan Son national Park, province of Phu Tho, northern Vietnam: altitude of about 300$400 \mathrm{~m}$ above sea level, from Natural forest, in the soil surface layer of 0-10cm, April 22, 2005.

Distribution: Until this moment it is recorded only in Vietnam; probably endemic.

Remarks: The new species is most similar to Papillacarus ogawai (Aoki, 1965), Papillacarus cruzae Corpuz-Raros, 1979, Papillacarus ramirezae (Corpuz-Raros, 1979) by sharing the morphology prodorsal, notogastral and branched neotrichous setae. However, $P$. benenensis is easily distinguishable from these species by some morphological signs (see table 2).

Acknowledgements: The study was supported by the Vietnamese NAFOSTED No.106.15.13.09. The authors wishe to express their thanks to Prof. Dr. Roy A. Norton, State University of New York, Syracuse, USA, for his consultations and help with collecting literature, for his partial thorough review of this manuscript and many valuable suggestions.

\section{REFERENCES}

1. Aoki J., 1965: Nature and Life Southeast Asia, 4: 129-193.

2. Balogh J. \& Balogh P., 1987: Acta Zoologica Hungarica, 33: 327-398.

3. Balogh J. \& Mahunka S., 1967: Zoologica Academiae Scientiarum Hungaricae, 13: 3974.

4. Corpuz-Raros L. A., 1979: Kalikasan, 8: 315-334.

5. Grandjean F., 1950: Archives de Zoologie experimentale et generale, 87: 95-161.

6. Hammer M., 1979: Biologiske Skrifter, 22: 1-79.

7. Jeleva M. \& Vu Q. M., 1987: Acta Zoologica Bulgarica, 33: 10-18.

8. Mahunka S., 1987: Annales HistoricoNaturales Musei Nationalis Hungarici, 79: 259-279.

9. Mahunka S., 1988: Acta Zoologica Hungarica, 34(2-3): 215-246.

10. Mahunka S., 1989: Folia Entomologica Hungarica, 50: 47-59.

11. Subías L. S., 2009: Listado sistemático, sinonímico y biogeográfico de los ácaros oribátidos (Acariformes: Oribatida) del mundo (excepto fósiles). (Originally published in Graellsia, 60. (número extraordinario), 3-305 (2004), Actualized en abril de 2009, 547 pp.). http://www.ucm.es/info/zoo/Artropodos/Cat alogo.pdf.

12. Vu Q. M. \& Nguyen T. T., 1982: BiologyAgriculture, 1(2): 27-29. Scientific Information of Hanoi University of Education.

13. Vu Q. M., 1984: Biology-Agriculture, 1(2): 11-16. Scientific Information of Hanoi University of Education.

14. Vu Q. M., Jeleva M. \& Tsonev I., 1985: Faunal-Ecological studies on soil Oribatid community (Acari: Oribatei) in some ecosystems in the northern part of Vietnam: 93-102. Proceedings of the Conference of Ecology and Environmental Protection, Sofia, Bulgaria.

15. Vu Q. M. \& Jeleva M., 1987: Vietnam of Journal of Biology, 9(3): 46-48.

16. Vu Q. M. \& Nguyen T. T., 2000: Journal of Biosciences, 25: 379-386.

17. Vu Q. M., 2007: Fauna of Vietnam, 21, Oribatida. H. Science and Techniques Publishing House. 


\title{
HAI LOÀI VE GIÁP MỚI (ACARI: ORIBATIDA) Ở VIÊT NAM
}

\author{
VŨ QUANG MẠNH, SERAEY G. ERMILOV, ĐÀO DUY TRINH
}

\section{TÓM TÁT}

Bài báo mô tả hai loài ve giáp (Acari: Oribatida) mới cho khoa học là Aokiella xuansoni sp. nov. Vu, Ermilov et Dao (Carabodidae) và Papillacarus benenensis sp. nov. Vu, Ermilov et Dao (Lohmanniidae).

Cả hai loài đều được mô tả trên cơ sở đặc điểm hình thái của các cá thể trưởng thành, thu bắt được trong các năm 2008-2009, từ hệ sinh thái đất của vườn quốc gia Xuân Sơn, tỉnh Phúc Thọ và vườn quốc gia Bến En, tỉnh Thanh Hóa, ở đai cao 300-400 m so với mặt nước biển; trong các sinh cảnh rừng tự nhiên và rừng nhân tác, trong tầng thảm lá rừng phủ trên mặt đất, ở lớp đất mặc $0-10 \mathrm{~cm}$ và lớp đất sâu $11-20 \mathrm{~cm}$. Holotype của chúng được lưu giữ tại bảo tàng Động vật, thuộc viện Động vật học, viện Hàn lâm khoa học Liên bang Nga St. Peterburg và Paratype của chúng được lưu giữ tại sưu tập mẫu của Trung tâm Đa dạng sih học (Cebred), trường đại học Sư phạm Hà Nội, Việt Nam.

Loài mới Aokiella xuansoni sp. nov. Vu, Ermilov et Dao thuộc họ Carabodidae C. L. Koch, 1836 có kích thước cơ thể nhỏ, trong khoảng $0,287-0,291 \mathrm{~mm} \times 0,122-0,123 \mathrm{~mm}$. Cơ thể loài màu nâu sẫm, bề mặt được bao phủ gồ ghề bởi các hoa văn dạng tròn, to và nhỏ khác nhau. Đôi lông $c$ chĩa thẳng phía trước, trong đó $c 1$ hơi dài hơn $c 2$; các lông $d a$ và $l a$ khá ngắn, nên không chạm tới phần gốc của lông $d m$ và $l m$.

Loài mới Papillacarus benenensis sp. nov. Vu, Ermilov et Dao thuộc họ Lohmanniidae Berlese, 1916, có kích thước cơ thể khá lớn, so với những loài cùng giống khác, trong khoảng 0,664-0,668 mm × 0,322-0,328 $\mathrm{mm}$. Lông se có phần thân lông dài, phần đỉnh dạng bàn chải mang khoảng 15 nhánh lông bên khá dài. Bề mặt cơ thể được bao phủ bởi hoa văn dạng lưới, với các mắt lưới dạng bỏng ngô. Mang 18 đôi lông no, với các phân nhánh tớ bên nhỏ, dạng cây thông, cùng với các xương kitin. Công thức lông cùng ngực và bụng Epimera là 10-9-5-4. 